Jurnal Reviu Akuntansi dan Keuangan, vol 9 no 3, p. 387-395

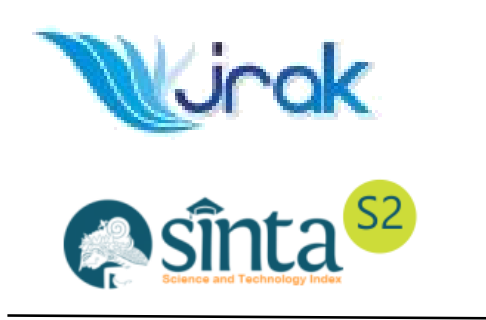

Website:

ejournal.umm.ac.id/index.php/jrak

Afiliation:

${ }^{1}$ Fakultas Ekonomi, UIN Maulana

Malik Ibrahim, Malang, Indonesia

*Correspondence:

indahoty@manajemen.uin-

malang.ac.id

DOI: $10.22219 /$ jrak.v9i3.69

Citation:

Yuliana, I., \& Kholilah. (2019). Investment Decisions, Gender Diversity And Firm Value: Is Gender Important In Indonesia?. Jurnal Reviu Akuntansi dan Keuangan, 9(3), 387-395.

Article Process

Submitted:

October 11, 2019

Reviewed:

October 24, 2019

Revised:

December 12, 2019

Accepted:

December 30, 2019

Office:

Department of Accounting

University of

Muhammadiyah Malang

GKB 2 Floor 3.

Jalan Raya Tlogomas 246,

Malang, East Java,

Indonesia

P-ISSN: 2615-2223

E-ISSN: 2088-0685
Article Type: Research Paper

\section{Investment Decisions, Gender Diversity And Firm Value: Is Gender Important In Indonesia?}

\author{
Indah Yuliana $^{1 *}$ and Kholilah ${ }^{1}$
}

\section{ABSTRACT}

The purposes of this research are to determine the effect of executive board gender diversity on firm value. Gender diversity shows that companies do not discriminate while evaluating employee performance. This diversity affects the fair competition conducted by employees to show the best performance so they can occupy the highest positions in the company. Gender diversity has the impact of a difference in the level of optimism, confidence, and risk preferences. The feminine nature of women influences the quality of investment decision making, which has an impact on increasing firm value. The signalling theory is used to describe the stakeholders perceived on investment decision making by female CEOs. Research using PLS in LQ45 registered companies in Indonesian Stock Exchange for the years 2014-2017. The results showed that the composition of the female CEO can mediate the relationship between investment decisions and firm value. The results have implications to support the increasing gender diversity in companies because the patriarchal culture adopted in Indonesia causes male domination in decision making both in the family, community, and the working environment.

KEYWORDS: Investment Decisions, Gender Diversity, Firm Value 
Yuliana \& Kholilah, Investment Decisions, Gender Diversity...

\section{INTRODUCTION}

The Executive Board plays a vital role in corporate investment decisions making. The Chief Executive Officer (CEO) as the decision controller must be able to prioritize rationality in investment decision making, besides the emotional and psychological factors of the CEO itself. One of the most studied executive board diversity is gender diversity (Bernile, Bhagwat, \& Yonker, 2018). Gender diversity can improve the quality of decision making (Campbell \& Vera, 2010; Lückerath-Rovers, 2013). Emphasis on gender diversity is the composition of women in the highest leadership of the company either as a board of directors or a board of commissioners (executive board).

Gender diversity is still shallow because of the assumption that the gentle nature of women is not suitable to be in the working environment that demands speed, accuracy, and assertiveness in decision making. Leadership diversity in developing countries shows a better trend than developed countries; the countries rank with the highest percentage of diversity are Russia (45\%), Lithuania and the Philippines (39\%), Thailand and Estonia $(37 \%)$, and Indonesia (36\%) (Thornton, 2017). The results of a World Bank survey in Indonesia state that the total percentage of company ownership by women is $22.1 \%$, of which 39 per cent are large-scale companies. The high number shows that women have a positive contribution to economic growth. A World Economic Forum (WEF) study in 2017 stated that women were able to boost the economic growth of US \$ 5.3 trillion.

Gender differences lead to differences in levels of optimism, confidence and risk preferences (Bacha \& Azouzi, 2019). Women have a bland, emotional, motherly, and other graceful attitudes. Meanwhile, male masculinity that tends to be reliable, rational, objective and more aggressive is considered more capable of making more appropriate long-term investment decisions because of higher risk preferences (Fakih, 2016). Whereas the gentle nature of women is associated with lower risk preferences, so decision making tends to be emotional logic. The gentle nature of women makes investment decisions to be more conservative to save the company from investment decision mistakes (Huang \& Kisgen, 2013). Gender diversity is an exciting thing to study in Indonesia because there is still an assumption that men are more suitable to occupy important positions in companies.

The existence of women as executive boards has a positive effect on firm value (Bernile et al., 2018; Campbell \& Vera, 2010; Dewi \& Dewi, 2016; Hernandez, Ugedo, \& Vera, 2015; Lückerath-Rovers, 2013; Triana \& Asri, 2017). This positive effect caused by several things. First, the market reacts positively to the company's long-term development (Campbell \& Vera, 2010). Second, the good relations developed by female CEOs to employees can enhance teamwork and maintain good relations with all stakeholders (Dewi \& Dewi, 2016; Lückerath-Rovers, 2013). Third, the addition of female CEOs will reduce information asymmetry (Triana \& Asri, 2017). Fourth, increasing company profitability (Bernile et al., 2018). Fifth, reduce the level of loans so that the risk of bankruptcy is low in the nonpublic entities (Hernandez et al., 2015).

Lower risk preferences lead to female CEOs choosing low-risk investment decisions so that it affects the quality of investment decision making. The low risk taken by female CEOs can increase the company's Return on Equity (ROE). In contrast to the results of the study, the high diversity of gender negatively affects the value of the company because diversity in corporate leadership causes conflict in management (Adnan, Sabli, \& Abdullah, 2013; Wellalage \& Locke, 2013). Inconsistent research on the effect of gender diversity on firm value is a gap in this study, so the purpose of this study is to determine the effect of gender diversity on investment decisions in order to increase firm value. Mediating in

JRAK 9.3 
gender diversity is still rarely done by other researchers. This research is important to support of increasing gender diversity in companies because the patriarchal culture adopted in Indonesia causes male domination in decision making both in the family, community, and the working environment.

\section{Research Hypothesis}

Signalling theory is a theory that explains the signs given by companies to financial report users. Signals are actions taken by management as a guide for investors about the management's view of the company's prospects (Brigham \& Houston, 2014). Companies with favourable prospects, choose to get new capital by adding debt rather than selling shares. Signal theory explains management's motives for providing financial statement information to external parties. This theory is relevant to study because of the information asymmetry. As a company manager, management has more information than external parties. The lack of internal party information about the company's prospects causes external parties to tend to give a low valuation of the company. Management can increase the firm value by reducing information asymmetry by giving signals to external parties in order to reduce uncertainty about the company's prospects.

The investment decision is the process of selecting one or more investment alternatives in the form of tangible assets or intangible assets in order to obtain profitable results (Sudana, 2011). Investment decisions are managerial decisions by allocating funds to various assets (Mardiyanto, 2009). The accuracy of investment decisions is determined based on the amount of profit given to investors. This decision is essential for management because the mindset of investors is that the company can generate cash inflow in the future beyond the initial investment value. The identification of investment opportunities is the initial step of the investor. So management obliges the investors to identify project profit prospects (Brigham \& Houston, 2014).

Investment decisions determine the overall amount of resources, the composition of assets and the level of risk. Investment decisions show that companies have alternative and investment opportunities to increase company growth. One of the investment decisions measurement is the Investment Opportunity Set (IOS). IOS describes the breadth of investment opportunities or opportunities that are determined by the company's capital expenditure. The width definition of IOS causes difficulties in measuring IOS. IOS proxies include the Capital Expenditure Ratio to Book Value of Assets (Dahlan \& Suwandi, 2016; Fenandar \& Raharja, 2012), Total Assets Growth (Dahlan \& Suwandi, 2016), Market to Book Value of Assets (MBVA) (Dahlan \& Suwandi, 2016)), Current Assets to Total Assets (Dahlan \& Suwandi, 2016; Harmono, 2009), and Price Earning Ratio (Dahlan \& Suwandi, 2016; Pamungkas \& Puspaningsih, 2013). MBVA measures the company's growth projections based on the number of assets used in the company (Dahlan \& Suwandi, 2016). Asset allocation differs between women and men depending on their level of confidence.

The level of investor confidence can affect firm value (Dewi \& Dewi, 2016). The role of the executive board in the company is an environmental linkage perspective and control role. Environmental linkage perspective describes the role of the executive board of the company and the environment (Dewi \& Dewi, 2016). This role has an impact on the role

JRAK of the executive board in protecting the interests of investors from uncertain environmental conditions (Dewi \& Dewi, 2016). The control role states that the executive 9.3 board understands the company's administrative processes so that they can control management (Dewi \& Dewi, 2016). Both of these roles affect self-serving behaviour that can increase shareholder value (Dewi \& Dewi, 2016). 
Yuliana \& Kholilah, Investment Decisions, Gender Diversity...

The signalling theory states that the election of the executive board aims to optimize investor interests. The diversity of the executive board can be measured in six dimensions, the presence of women, age, citizenship, formal education, financial expertise, and experience (Bernile et al., 2018). The diversity of the executive board shows that in the election of the executive board, the company has implemented good corporate governance (GCG). The diversity of the executive board can increase transparency, accountability, responsibility, independence and fairness for investors. GCG improvement can persuade investor about the high return possibility.

Gender diversity increases the firm value because it gives a sign that the company does not discriminate in the selection of company leaders (Dewi \& Dewi, 2016). All parties have the same opportunity to show their best performance and get the highest position in the company because of that performance. This opportunity gives a positive signal to investors that impact on increasing the firm value. The increase in the composition of women in the executive board should continue to be improved so that the community provides a positive perceived of management that has an impact on increasing firm value (Campbell \& Vera, 2010).

The higher the diversity, the more diverse alternative solutions to problems due to the heterogeneity of the perspectives of individual members of the executive board (Gómez, Lafuente, \& Vaillant, 2018). The homogeneity of perceptions, views and background experiences of executive board members results in decisions made in one colour, not unique, and rigidly which are contrary to the mechanism of GCG. The diversity of executive board members strengthens the company's ability to face the challenges and dynamics of the business environment.

Gender diversity in the composition of the executive board has a positive effect on improving the quality of decision making so that it has an impact on increasing company value (Campbell \& Vera, 2010; Dewi \& Dewi, 2016; Gómez et al., 2018; Lückerath-Rovers, 2013; Triana \& Asri, 2017). In contrast to the study, other findings showed a negative relationship between female CEOs and investment decisions because female CEOs did not have a significant relationship in capital addition decisions either with debt issuance or equity (Adnan et al., 2013; Wellalage \& Locke, 2013). This decision directed at lower risktaking preferences by female CEOs, so they prefer debt financing overstock sales. The conceptual framework of the study presented in Figure 1 below.

Figure 1.

Conceptual

Framework

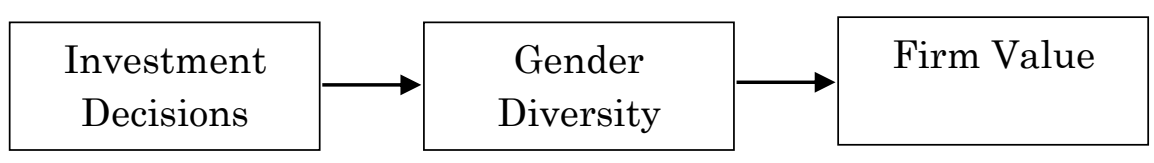

\section{H: Investment Decisions Affects on Firm V alue Through Gender Diversity}

\section{METHOD}

This research is a quantitative descriptive. The population in this study were 56 samples from 14 companies listed in the 2014-2017 LQ-45 stock index. The sampling technique used was purposive sampling method. Following is a list of 14 research sample companies, PT. Corporindo (AKRA), PT. Bumi Serpong Damai (BSDE), PT. Gudang Garam (GGRM), PT. Indofood CBP Sukses Makmur (ICBP), PT. Kalbe Farma (KLBF), PT. Lippo Karawaci (LPKR), PT. London Sumatra Plantation Company (LSIP), PT. Media Nusantara Citra (MNCN), PT. Pakuwon Jati (PWON), PT. Summarecon Agung (SMRA), 
PT. Telekomunikasi Indonesia (TLKM), PT. Unilever Indonesia (UNVR), and PT. Wijaya Karya (WIKA).

The independent variable is the investment decision measured by MBVA. This ratio is used to see the company's growth potential based on assets used in the company's operations (Dahlan \& Suwandi, 2016). The formula used to calculate MBVA is as follows.

$$
\text { MBVA }=\frac{\text { (Total Asset-Total Equity) }+(\text { Issued Share } \mathrm{x} \text { Share Price) }}{\text { Total Asset }}
$$

The dependent variable is the company value measured by Tobin's Q (TOBQ) ratio. The last variable used in the study is the mediating variable (PWOMCEO) measured by the percentage of the composition of female CEOs compared to all CEOs in the company (Wellalage \& Locke, 2013). Data analysis uses descriptive statistics and Partial Least Square (PLS) for structural testing models

\section{RESULTS AND DISCUSSION}

\section{Statistics Summary and Hypothesis Testing}

Descriptive analysis is used to provide a general description of the minimum, maximum, and average values of the variables used. The results of the descriptive analysis presented in Table 1.

The results of Table 1 show that the composition of female CEOs in the company fluctuates every year. The highest percentage obtained in 2017 at 20\%, the lowest in 2014 at $18.4 \%$, and an average of $19.6 \%$ and $19.2 \%$ in 2015 and 2017 . These results indicate that CEO diversity in Indonesia is still shallow, with the composition of men in the CEO ranks above $80 \%$. The composition of women in the executive board should be $40 \%$ (Campbell \& Vera, 2010). The low level of involvement of women in the working environment caused by the patriarchal culture adopted in Indonesia (Kusumawardhana \& Abbas, 2018). Firm value and investment decisions also experience fluctuating changes each year. The highest firm value obtained in 2014 at 3.24 and the lowest in 2016 at 2.94 . The highest investment decision obtained in 2014 of 3.55 and the lowest in 2015.

Table 2 shows that the samples taken in this study were 56 samples. The minimum TOBQ value is 0.28 , the maximum value is 22.99 , and the average value is 3.088 . The minimum PWOMCEO value is 6 per cent, the maximum value is $45 \%$, and the average value is $19 \%$.

\begin{tabular}{lcccc}
\hline \multirow{2}{*}{ Variable } & \multicolumn{4}{c}{ Years } \\
& $\mathbf{2 0 1 4}$ & $\mathbf{2 0 1 5}$ & $\mathbf{2 0 1 6}$ & $\mathbf{2 0 1 7}$ \\
\hline TOBQ & 3,24 & 2,97 & 2,94 & 3,22 \\
PWOMCEO & 0,184 & 0,196 & 0,200 & 0,192 \\
MBVA & 3,55 & 3,23 & 3,24 & 3,51 \\
\hline
\end{tabular}

Table 1. Descriptive Test

\begin{tabular}{lccccc}
\hline \multicolumn{1}{c}{ Variable } & N & Min. & Max. & Mean & Std. Dev \\
\hline TOBQ & 56 & 0,28 & 22,99 & 3,0888 & 4,7270 \\
PWOMCEO & 56 & 0,06 & 0,45 & 0,1931 & 0,0979 \\
MBVA & 56 & 0,67 & 23,29 & 3,3830 & 4,7183 \\
\hline
\end{tabular}

Table 2.

Descriptive Result 
Meanwhile, the minimum value of MBVA is 0.67 , the maximum value is 23.29 , and the average value is 3.38 . The dependent variable is the investment decision with the lowest value of 0.67 and the highest value of 23.29 .

Table 3.

\begin{tabular}{lccccc}
\hline & Original & Mean & (STDEV) & T Statistics & P \\
\hline PWOMCEO -> MBVA & 0.212 & 0.208 & 0.102 & 2,083 & 0.038 \\
PWOMCEO -> TOBQ & 0.111 & 0.105 & 0.046 & 2.421 & 0.00 \\
\hline
\end{tabular}

Coefficient

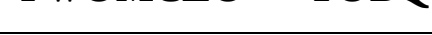

\begin{tabular}{lccccc}
\hline & $\begin{array}{c}\text { Original } \\
\text { Sample } \\
(\mathbf{O})\end{array}$ & $\begin{array}{c}\text { Sample } \\
\text { Mean } \\
(\mathbf{M})\end{array}$ & $\begin{array}{c}\text { Standard } \\
\text { Deviation } \\
\text { (STDEV) }\end{array}$ & $\begin{array}{c}\text { T } \\
\text { Statistics } \\
(\mid \mathbf{O} / \text { STD } \\
\text { EV } \mid)\end{array}$ & $\begin{array}{c}\mathbf{P} \\
\text { Values }\end{array}$ \\
\hline $\begin{array}{l}\text { PWOMCEO -> } \\
\text { TOBQ }\end{array}$ & 0,111 & 0,105 & 0,046 & 2,421 & 0,0016 \\
$\begin{array}{l}\text { Mediating Effect } \\
\text { - -> TOBQ }\end{array}$ & 0,399 & 0,392 & 0,055 & 7,305 & 0,000 \\
\hline
\end{tabular}

Table 3 shows the relationship between the variables in the study. The results of the curve test show the relationship between the independent variable, mediating variable and the linear dependent variable. This relationship indicates linearity, which is the relationship between the independent variable, and the dependent variable

Table 4 shows that all constructs are positively related and affect firm value. The significance value of the effect shown by the $P$ value of 0,0016 and 0,000 . Besides, the $T$ Statistic is 7,305 , this value is higher than two, which means that there is a mediating relationship between investment decisions and the composition of the female CEO on the executive board to the firm value.

\section{Discussion}

The MBVA ratio is an IOS measurement based on the price that shows the company's growth projections that reflected in the exceeds of stock market price than the book value (Dahlan \& Suwandi, 2016). Investors use this ratio as a material consideration in the selection of investment decisions. The higher the MBVA, the more assets used, the greater the possibility of an increase in stock prices, and the higher the probability of an increase in stock returns. The use of ratios is under the signalling theory that explains the relationship between information provided by companies to investment decision making. Signals given by companies provide instructions to investors about the projected growth of the company, profitability, projections of future cash flows and valuation of investment feasibility. Transparent, relevant, reliable, complete and timely information about the general condition of the company, whether that happened in the past, present, or in the future is needed by investors to analyze investment decisions. If the information is positive, it expected that the market would also react positively (Jogiyanto, 2015).

The results showed that the proportion of women on the board directors was higher than in the board commissioners. This result means that women are more dominant as investment decision-makers than as supervisors. The role of the board of directors following Financial Services Authority Regulation No.10 / POJK.04 / 2018 article 48 is responsible for implementing business plans and disseminating business plans to all 
investment manager employees, while the board of commissioners is responsible for supervising the implementation of business plans. The description of the directors' duties under these regulations is the holding of the Annual General Meeting of Shareholders (RUPS), other coordination of company activities, and the establishment of policies and strategies according to the company's vision and mission. This task requires the board of directors to make decisions that are effective, appropriate, fast, independent and prioritize the interests of the company rather than personal interests. This demand can increase the ability of the board of directors to carry out their duties independently and critically in formulating policies and compiling plans or work programs in finance and investment. The board of directors forms an investment committee to set investment targets, investment limits, and cooperate with the Investment Group Head establishes an investment portfolio allocation policy to produce a reasonable rate of return.

PLS test results show that gender diversity in the executive board can mediate the relationship of investment decisions with the firm value. The composition number of women on the executive board can increase the quality of investment decisions on firm value. The higher the proportion of female CEOs on the executive board, the higher the level of influence of investment decisions on firm value. Female CEOs have unique characteristics that can create added value for the company because women bring new perspectives on complex issues. This perspective can help correct information biases in the formulation of strategies and solving company problems. This perspective is in line with the signalling theory, which states that all management decisions become positive or negative signals to the company.

The selection of the executive board based on the presence of women, age, citizenship, formal education, financial expertise, and experience (Bernile et al., 2018) shows that the company has implemented good GCG. Proper GCG implementation increases investor confidence that the company has fulfilled the principles of transparency, accountability, responsibility, independence and fairness for investors. Investors optimist that investing in companies has excellent potential in the future so that the market values will be increased. The results of this study are in line with the research of Campbell and Vera, 2010; Luckerath-Rovers, 2013; Hernandez et al., 2015; Bernile et al., 2018; Dewi, 2016; and Triana \& Asri, 2017 which shows that gender diversity within the executive board has a positive effect on investment decision making that has an impact on the firm value. Gender diversity can improve the quality of decision making. The companies ROE increased significantly with female CEOs.

Female CEOs can produce better firm performance (Dewi \& Dewi, 2016; LückerathRovers, 2013). Better results are given because women avoid risk and are conservative in decision making (Hernandez et al., 2015), tend to think more broadly in a democratic and participatory impact (Dezsö \& Ross, 2012) and more concerned with social responsibility and ethical behaviour (Lückerath-Rovers, 2013). The gentle nature of women causes female CEOs to have better communication and listening skills in the company's daily operations (Lückerath-Rovers, 2013). This ability causes the involvement of female CEOs in the decision-making process, provide new views and challenges that have a positive impact on the output of decisions taken.

The women's leadership characterized as the mother, the pet, the sex object, and the iron

9.3 maiden (Kanter, 1976). The mother means the female CEO behaves like a mother who strives for all the best things for her family so that the female CEO has a sympathetic nature, the ability to be a good listener, and the ease of pouring out problems that have 
an impact on the ease of problem-solving. The pet means that a female CEO can be a favourite of his subordinates. This feeling has an impact on the intention of subordinates to maintain the CEO because of the assumption that the CEO is a close person, so there is no awkward feeling in interacting. The sex object is the ability of female CEOs to be encouragement for employees. This factor causes the initiative of employees to work harder. Orders from superiors do not cause increased employee motivation, but because of employee personal awareness. The iron maiden means that women have firmness in their leadership so that with all of their feminine instincts, female CEOs are also able to be assertive.

\section{CONCLUSION}

This study concludes that the composition of the number of women on the executive board can mediate the influence of investment decisions on company value. The feminine nature of women causes women to be more conservative and conservative in making decisions so that it has an impact on the quality of investment decisions that affect firm value. The results also showed that the presence of women in the composition of the executive council was still shallow, around $20 \%$ because of the patriarchal culture adopted in Indonesia. This result has implications for the women increasing proportion on the executive board.

Limitations of this study are the measurement of investment decisions, gender diversity, and firm value. Suggestions for the next research are the addition of measurements for each variable such as the Capital Expenditure Ratio to Book Value of Assets, Total Assets, Current Assets to Total, and Price Earning Ratio for measuring investment decisions. Gender diversity variables measured by the catalyst method, McKinsey, or the relative diversity method. The use of price book value (PBV) to measure the firm value because the comparison of the stock market price with the book value of shares illustrates the investor's assessment of the company. Besides, research needs conducting on several sectors and subsectors of companies in Indonesia.

\section{REFERENCES}

Adnan, M. F., Sabli, N., \& Abdullah, A. (2013). Relationship between Board Gender Diversity \& Firm Performance. Gading Journal for the Social Sciences, 17(02).

Bacha, S., \& Azouzi, M. A. (2019). How gender and emotions bias the credit decisionmaking in banking firms. Journal of Behavioral and Experimental Finance, 22, 183-191.

Bernile, G., Bhagwat, V., \& Yonker, S. (2018). Board diversity, firm risk, and corporate policies. Journal of Financial Economics, 127(3), 588-612.

Brigham, E. F., \& Houston. (2014). Dasar-Dasar Manajemen Keuangan (11th ed.). Jakarta: Salemba Empat.

Campbell, K., \& Vera, A. M. (2010). Female board appointments and firm valuation: Short and long-term effects. Journal of Management and Governance, 14(1), 37-59.

Dahlan, F., \& Suwandi, M. (2016). Pengaruh Keputusan Investasi Terhadap Nilai Perusahaan Jasa Perbankan yang Terdaftar di Bursa Efek Indonesia. Jurnal Ilmiah Akuntansi Peradaban, 2(1), 64-88.

Dewi, G., \& Dewi, A. (2016). Pengaruh Diversitas Dewan Komisaris Dan Direksi Pada Nilai Perusahaan Pada Perusahaan Sektor Keuangan Yang Terdaftar Di Bursa Efek 
Indonesia Tahun 2009-2013. E-Jurnal Akuntansi, 16(1), 812-836.

Dezsö, C. L., \& Ross, D. G. (2012). Does female representation in top management improve firm performance? A panel data investigation. Strategic Management Journal, $33(9)$.

Fakih, M. (2016). Analisis Gender dan Transformasi Sosial Edisi 15. Yogyakarta: INSISTPress.

Fenandar, G. I., \& Raharja, S. (2012). Pengaruh Keputusan Investasi, Keputusan Pendanaan, Dan Kebijakan Dividen Terhadap Nilai Perusahaan. Diponegoro Journal of Accounting, 1(2), 1-10.

Gómez, J. M., Lafuente, E., \& Vaillant, Y. (2018). Gender diversity in the board, women's leadership and business performance. Gender in Management, 33(2), 104-122.

Harmono. (2009). Manajemen Keuangan Berbasis Balanced Scorecard (Pendekatan Teori, Kasus, dan Riset Bisnis). Jakarta: Bumi Aksara.

Hernandez, M. I. G., Ugedo, J. F. M., \& Vera, A. M. (2015). The influence of gender on financial decisions: Evidence from small start-up firms in Spain. E a M: Ekonomie a Management, 18(4), 93-107.

Huang, J., \& Kisgen, D. J. (2013). Gender and corporate finance: Are male executives overconfident relative to female executives? Journal of Financial Economics, 108(3), 822839.

Jogiyanto, H. (2015). Teori Portofolio dan Analisis Investasi. Yogyakarta: BPFE.

Kanter, R. M. (1976). The Impact of Hierarchical Structures on the Work Behavior of Women and Men. Social Problems, 23(4), 415-430.

Kusumawardhana, I., \& Abbas, R. J. (2018). Indonesia di Persimpangan: Urgensi “UndangUndang Kesetaraan dan Keadilan Gender" di Indonesia Pasca Deklarasi Bersama Buenos Aires pada Tahun 2017. Jurnal HAM, 9(2), 153-174.

Lückerath-Rovers, M. (2013). Women on boards and firm performance. Journal of Management and Governance, 17(2), 491-509.

Mardiyanto, H. (2009). Intisari Manajemen Keuangan. Jakarta: Grasindo.

Pamungkas, H. S., \& Puspaningsih, A. (2013). Pengaruh Keputusan Investasi, Keputusan Pendanaan, Kebijakan Dividen Dan Ukuran Perusahaan Terhadap Nilai Perusahaan. Jurnal Ilmu Dan Riset Akuntansi, 1-10.

Sudana, I. M. (2011). Manajemen Kenangan Perusabaan Teori dan Praktek. Jakarta: Erlangga.

Thornton, G. (2017). Women in Business.

Triana, \& Asri, M. (2017). the Impact of Female Directors on Firm Performance: Evidence From Indonesia. Journal of Indonesian Economy and Business, 31(1), 19-32.

JRAK Wellalage, N. H., \& Locke, S. (2013). Women on board, firm financial performance and agency costs. Asian Journal of Business Ethics, 2(2), 113-127. 